УДК 636.082

(C) 2012

Небилиця М. С., Новицький В. П., кандидати сільськогосподарських наук

Черкаська дослідна станція біоресурсів ІРГТ НААН

Миронченко В. Г., зоотехнік-селекціонер

ТОВ «СП «Золотоніський»

\title{
СЕЛЕКЦІЙНО-ГЕНЕТИЧНА ОЦІНКА СВИНЕЙ АНГЛІЙСЬКОЇ СЕЛЕКЦІї ТОВ «СП «ЗОЛОТОНІСЬКИЙ» ЗА ПОКАЗНИКАМИ ВЛАСНОЇ ПРОДУКТИВНОСТІ
}

\section{Рецензент - кандидат сільськогосподарських наук Ю. М. Сотніченко}

Відмічено, щзо в процесі роботи з тваринами спеияіалізованих порід імпортного походження бальна оцінка за комплексним класом є наразі малоінформативною. Встановлено високий коефіцієнт кореляції $(r=-0,825)$ між значеннями оціночних індексів Ів та Ір. Оиінка ремонтного молодняку свиней на основі наведених індексів є більш точною, порівняно з оцінками за незалежними рівнями та рангами. Зокрема, у результаті проведених досліджень встановлено, що за показниками очіночних індексів Ів та Ір серед тварин великої білої породи англійського походження, кнуриі вірогідно переважали своӥх ровеснииь.

Ключові слова: свині, порода, лінія, родина, продуктивність, метод оцінки, селекція.

Постановка проблеми. Однією 3 головних умов науково-технічного прогресу в свинарстві $€$ широке впровадження сучасних досягнень у галузі генетики та селекції тварин, а також комплексу інтенсивних технологій, що дають можливість підвищити їх продуктивність і знизити собівартість продукції. У свою чергу, основним джерелом підвищення генетичного потенціалу свиней $є$ точність оцінки і подальший добір для відтворення найбільш цінних у племінному відношенні тварин [4].

Аналіз основних досліджень і публікацій, у яких започатковано розв'язання проблеми. У світовій практиці оцінка генотипу тварин проводиться за допомогою різних інформаційних джерел: за даними продуктивності предків, сибсів i напівсибсів, власної продуктивності та продуктивності потомків. Використовуються як окремі 3 перелічених джерел, так і їх комбінації. При цьому нерідко спостерігаються розбіжності в оцінках, отриманих плідниками, у ході визначення їх племінної цінності різними методами $[1,3]$.

Індексна селекція у сучасному світовому свинарстві набула значного поширення. Суть такого підходу полягає в тому, що для подальшої роботи у стаді відбираються тварини на основі інте- грованої оцінки їх селекційної цінності. В умовах України найширше застосування в свинарстві отримала селекція за незалежними рівнями, основні положення якої викладені в Інструкції 3 бонітування (2003). Для успішного проведення селекційної роботи необхідно вирішити 4 групи завдань: оцінити продуктивність тварини, визначити їі селекційну цінність, провести добір і підбір та спарувати тварини для отримання запланованого потомства. Особлива увага надається оцінці селекційної цінності, що базується на результатах фенотипової оцінки продуктивності тварин і є передумовою для проведення оптимального добору [2]. Тому порівняльний аналіз поширених методів оцінки свиней за показниками власної продуктивності нині є актуальним.

Мета досліджень - порівняльний аналіз окремих методів оцінки продуктивності свиней для удосконалення селекційного процесу.

Матеріал i методика проведення досліджень. Роботу проводили в селекційному центрі ТОВ «СП «Золотоніський» Черкаської області на поголів'ї свиней порід велика біла і ландрас англійської селекції.

Оцінку тварин здійснювали за наступними оціночними індексами:

1) репродуктивних якостей свиноматок Л. Лаша в модифікації М. Д. Березовського та Д. В. Ломако:

$\mathrm{I}=\mathrm{n}_{0}+2 \mathrm{n}_{60}+35 \mathrm{G}$

де: I - індекс відтворювальних якостей;

$\mathrm{n}_{0}$ - кількість поросят при народженні, гол.;

$\mathrm{n}_{60}$ - кількість поросят при відлученні, гол.;

$\mathrm{G}$ - середньодобовий приріст поросят до відлучення, кг;

2) ремонтного молодняку за енергією росту йа товщиною шпику:

Ip $=\mathrm{K}: \mathrm{A}^{2} / \mathrm{B}: \mathrm{C}$,

де: Ip - індекс оцінки за енергією росту й товщиною шпику; 
К - вік досягнення маси 100 кг, дн.;

А - абсолютний приріст за обліковий період, кг;

В - обліковий період вирощування, дн.;

C - товщина шпику на рівні 6-7 ребра, см.

3) ремонтного молодняку за середньодобовим приростом та товщиною шпику:

$\mathrm{I}_{\mathrm{B}}=100+(242 \times \mathrm{k})-(4,13 \times \mathrm{L})$

де: Ів - індекс оцінки за середньодобовим приростом й товщиною шпику;

$\mathrm{k}$ - середньодобовий приріст, кг;

$\mathrm{L}$ - товщина шпику, мм.

Оцінку молодняку свиней за власною продуктивністю в розрізі лінійної та родинної належності проводили також шляхом визначення рангу в ряду даних: віку досягнення живої маси 100 кг, довжини тулуба та товщини шпику в 100 кг. За сумою рангів, розділеною на число доданків, визначали цінність молодняку кожної лінії чи родини (чим менша частка, тим вища цінність). Крім того проводили оцінку молодняку свиней за власною продуктивністю за незалежними рівнями, основні положення якої викладені в Iнструкції з бонітування (2003).

Результати досліджень. Аналізуючи одержані дані слід відмітити, що свиноматки породи ландрас мали вищий показник оціночного індексу репродуктивних якостей $(43,4 \pm 0,2 ; \mathrm{P}>0,95)$, порівняно 3 тваринами великої білої породи. Проте кращими показниками відтворювальної здатності характеризувалися свиноматки великої білої породи, у яких період «відлучення - результативне парування» становив $21,0 \pm 1,65$ діб при $\mathrm{P}>0,999$ (табл. 1).

У ході проведення досліджень установлені ко- ефіцієнти кореляції (r) між показниками багатоплідності свиноматок згаданих порід і кількістю поросят при відлученні, які дорівнювали 0,42 i 0,53 відповідно. Аналіз досліджень свідчить також про існування позитивного зв'язку між показниками багатоплідності й товщини сала у свиноматок вищезгаданих порід $(\mathrm{r}=0,24 \mathrm{i} \mathrm{r}=0,20)$.

Крім цього вивчали показники власної продуктивності молодняку свиней обох порід (за контрольного вирощування) в розрізі статевої та лінійної належності (табл. 2, 3). Так, установлено, що за віком досягнення маси 100 кг $(188 \pm 2$ діб; Р $>0,99$ діб), середньодобовим приростом $(580 \pm 8$ г; Р $>0,99)$, довжиною тулуба ( $129 \pm 0,3 \mathrm{~cm}$; $\mathrm{P}>0,999)$ й оціночними індексами Iв та Ip (від-

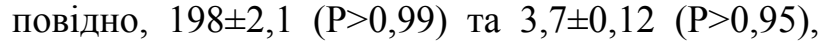
кнурці великої білої породи вірогідно переважали своїх ровесниць.

У розрізі родинної належності кращими показниками продуктивності характеризувалися свинки родини Іст Лесс, які вірогідно переважали ровесниць за показниками скороспілості $(183 \pm 6$ діб; Р $>0,95)$ та середньодобового приросту $(592 \pm 23$ г; $\mathrm{P}>0,999)$. Дещо гіршими за вищезазначеними показниками були свинки родин Блекбеppi та Фенні (по 208 \pm 5 діб та $510 \pm 13 \ldots 512 \pm 13$ г; $\mathrm{P}>0,95)$. В ході оцінки ремонтного молодняку породи ландрас (табл. 3) установлено, що за показниками віку досягнення живої маси 100 кг (173 2 діб), середньодобового приросту (631 \pm 8 г), довжини тулуба (132 $\pm 0,4$ см) і оціночних індексів Iв та Ip

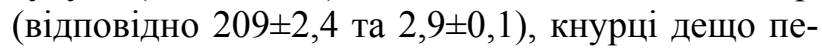
реважали свинок-ровесниць, проте різниця була невірогідною.

\section{1. Результати оцінки відтворювальних якостей свиноматок}

$\begin{array}{|c|c|c|}\hline \multirow{2}{*}{\text { Показник }} & \multicolumn{2}{|c|}{\text { Порода }} \\$\cline { 2 - 3 } & \text {$\left.велика біла, } \mathrm{n}=435 & \text { ландрас, } \mathrm{n}=558 \\ \hline \text { Багатоплідність, гол. } & 10,8 \pm 0,1 & 10,8 \pm 0,1 \\ \hline \text { Кількість відлучених поросят, гол. } & 9,4 \pm 0,1 & 9,5 \pm 0,1 \\ \hline \text { Жива маса гнізда поросят у 60 діб, кг } & 218,4 \pm 1,6 & 227,2 \pm 1,4^{* * *} \\ \hline \text { Індекс репродуктивних якостей } & 42,8 \pm 0,2 & 43,4 \pm 0,2^{*} \\ \hline \text { Період «відлучення-парування», діб } & 21 \pm 1,65^{* * *} & 36 \pm 1,8 \\ \hline \text { Коефіцієнти кореляції, } r \text { : } & 0,12^{*} & 0,05 \\ \hline \text { жива маса свиноматок - багатоплідність } & 0,06 & -0,01 \\ \hline \text { жива маса свиноматок - кількість поросят при відлученні } & 0,19^{* * *} & 0,05 \\ \hline \text { жива маса свиноматок - маса гнізда поросят } \\ \text { при відлученні }\end{array}\right)$

Примітка. Тут і надалі різниця між даними, позначеними наступними знаками, є вірогідною порівняно до контролю: ${ }^{*}-$ при Р $>0,95 ;{ }^{* *}-$ при Р $>0,99 ;{ }^{* * *}-$ при $\mathrm{P}>0,99$ 
СІЛЬСЬКЕ ГОСПОДАРСТВО. ТВАРИННИЦТВО

\section{2. Результати оцінки молодняку свиней великої білої породи за показниками власної} продуктивності в розрізі лінійної належності, $M \pm m$

\begin{tabular}{|c|c|c|c|c|c|c|c|c|c|c|}
\hline Лінія & $\mathrm{n}$ & 苞 & $\begin{array}{c}\text { Вік досяг- } \\
\text { нення } \\
100 \text { кг, діб }\end{array}$ & $\begin{array}{c}\text { Середньо- } \\
\text { добовий } \\
\text { приріст, г }\end{array}$ & $\begin{array}{c}\text { Довжина } \\
\text { тулуба, см }\end{array}$ & $\begin{array}{c}\text { Товщина } \\
\text { шпику в } \\
100 \text { кг, мм } \\
\end{array}$ & $\begin{array}{c}\text { Сере- } \\
\text { дній } \\
\text { бал } \\
\end{array}$ & Ів & Ip & Ранг \\
\hline \multirow{2}{*}{ Уісто } & 20 & $\hat{0}$ & $186 \pm 3 * *$ & $582 \pm 10 * *$ & $129 \pm 0,5$ & $10,0 \pm 0,3$ & 4,0 & $198 * *$ & $3,5^{* *}$ & 3,0 \\
\hline & 22 & $q$ & $203 \pm 5$ & $526 \pm 13$ & $128 \pm 0,5$ & $10,0 \pm 0,2$ & 4,0 & 186 & 4,5 & 5,7 \\
\hline \multirow{2}{*}{ Ч. Бой } & 20 & $\hat{0}$ & $190 \pm 4$ & $566 \pm 15$ & $129 \pm 0,7 * * *$ & $11,0 \pm 0,4$ & 4,0 & 194 & 3,7 & 4,3 \\
\hline & 8 & $q$ & $187 \pm 7$ & $577 \pm 23$ & $123 \pm 1,4$ & $12,0 \pm 1,4$ & 3,7 & 192 & 3,5 & 5,7 \\
\hline \multirow{2}{*}{ Вайсс } & 19 & $\hat{0}$ & $188 \pm 5$ & $592 \pm 28 *$ & $129 \pm 0,7 * * *$ & $10,0 \pm 0,4$ & 4,0 & $203^{*}$ & 4,0 & 3,7 \\
\hline & 7 & q & $202 \pm 5$ & $523 \pm 14$ & $124 \pm 0,6$ & $10,0 \pm 0,4$ & 3,7 & 184 & 4,3 & 6,3 \\
\hline \multirow{2}{*}{ Альпіне } & 18 & $\hat{0}$ & $182 \pm 6^{*}$ & $602 \pm 20 *$ & $130 \pm 0,8^{*}$ & $10,0 \pm 0,4$ & 4,0 & 204 & 3,5 & 2,3 \\
\hline & 16 & q & $199 \pm 5$ & $546 \pm 15$ & $127 \pm 1,1$ & $11,0 \pm 0,3$ & 4,0 & 188 & 3,9 & 5,7 \\
\hline \multirow{2}{*}{ Денні } & 6 & $\hat{0}$ & $190 \pm 5$ & $563 \pm 16$ & $131 \pm 0,7 * *$ & $9,3 \pm 0,4$ & 4,0 & 198 & 4,1 & 3,0 \\
\hline & 8 & $q$ & $180 \pm 7$ & $604 \pm 27$ & $127 \pm 0,7$ & $10,0 \pm 0,4$ & 4,0 & 206 & 3,4 & 3,0 \\
\hline Ч. Турк & 6 & $\hat{0}$ & $186 \pm 9$ & $582 \pm 34$ & $132 \pm 1,7$ & $11,0 \pm 0,6$ & 4,0 & 194 & 3,2 & 2,3 \\
\hline \multirow{3}{*}{$\begin{array}{l}\text { У серед- } \\
\text { ньому }\end{array}$} & 89 & 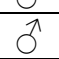 & $188 \pm 2 * *$ & $580 \pm 8 * *$ & $129 \pm 0,3 * * *$ & $10,0 \pm 0,2$ & 4,0 & $198 * *$ & $3,7^{*}$ & 3,7 \\
\hline & 61 & $q$ & $198 \pm 3$ & $545 \pm 8$ & $126 \pm 0,5$ & $10,0 \pm 0,2$ & 4,0 & 189 & 4,1 & 5,3 \\
\hline & $\pi$ & & -10 & +35 & +3 & 0 & 0 & +9 & $-0,4$ & $-1,6$ \\
\hline
\end{tabular}

3. Результати оцінки молодняку свиней породи ландрас за показниками власної продуктивності в розрізі лінійної належності

\begin{tabular}{|c|c|c|c|c|c|c|c|c|c|c|}
\hline Лінія & $\mathrm{n}$ & $\stackrel{\vec{E}}{\tilde{U}}$ & $\begin{array}{c}\text { Вік досяг- } \\
\text { нення } \\
100 \text { кг, діб }\end{array}$ & $\begin{array}{c}\text { Середньо- } \\
\text { добовий } \\
\text { приріст, г }\end{array}$ & $\begin{array}{c}\text { Довжина } \\
\text { тулуба, см }\end{array}$ & $\begin{array}{c}\text { Товщина } \\
\text { шпику в } \\
100 \text { кг, мм }\end{array}$ & $\begin{array}{l}\text { Cере- } \\
\text { дній } \\
\text { бал }\end{array}$ & Ів & Ip & Ранг \\
\hline \multirow{2}{*}{ Енорм } & 34 & $\hat{0}$ & $171 \pm 2$ & $636 \pm 11$ & $131 \pm 0,6$ & $10,6 \pm 0,3$ & 4,0 & 210 & $2,8^{*}$ & 3,7 \\
\hline & 17 & q & $183 \pm 6$ & $596 \pm 24$ & $128 \pm 1,2$ & $9,7 \pm 0,4$ & 3,7 & 204 & 3,8 & 5,0 \\
\hline \multirow{2}{*}{ Нектон } & 14 & $\hat{0}$ & $185 \pm 5$ & $580 \pm 21$ & $130 \pm 1,1 * *$ & $10,5 \pm 0,6$ & 3,7 & 197 & 3,5 & 6,3 \\
\hline & 8 & q & $189 \pm 7$ & $556 \pm 19$ & $125 \pm 1,2$ & $10,0 \pm 0,5$ & 3,7 & 193 & 4,0 & 7,0 \\
\hline \multirow{2}{*}{ Овазіон } & 20 & $\hat{O}$ & $169 \pm 2$ & $643 \pm 10$ & $132 \pm 0,9$ & $10,8 \pm 0,3$ & 4,0 & 211 & 2,7 & 4,3 \\
\hline & 7 & q & $179 \pm 7$ & $603 \pm 26$ & $131 \pm 0,6$ & $9,8 \pm 0,2 * *$ & 4,0 & 206 & 3,4 & 4,3 \\
\hline \multirow{2}{*}{ Паста } & 12 & $\hat{0}$ & $175 \pm 7$ & $636 \pm 38$ & $131 \pm 1,2$ & $10,9 \pm 0,6$ & 4,0 & 209 & 2,9 & 6,0 \\
\hline & 5 & q & $187 \pm 4$ & $574 \pm 15$ & $130 \pm 2,3$ & $9,6 \pm 0,7$ & 4,0 & 199 & 3,8 & 5,0 \\
\hline Нотіс & 3 & $\hat{0}$ & $157 \pm 2 * * *$ & $700 \pm 9 * * *$ & $138 \pm 2,2 * *$ & $10,4 \pm 1,1$ & 4,0 & $227 * *$ & $2,3 *$ & 2,3 \\
\hline \multirow{3}{*}{$\begin{array}{l}\text { У серед- } \\
\text { ньому }\end{array}$} & 83 & $\hat{0}$ & $173 \pm 2$ & $631 \pm 8$ & $132 \pm 0,4$ & $10,7 \pm 0,2$ & 4,0 & 209 & 2,9 & 4,7 \\
\hline & 37 & 오․ & $176 \pm 3$ & $616 \pm 12$ & $131 \pm 0,7$ & $10,0 \pm 0,3 *$ & 4,0 & 206 & 3,2 & 4,3 \\
\hline & & & -3 & +15 & +1 & $+0,7$ & 0 & +3 & $-0,3$ & $-0,4$ \\
\hline
\end{tabular}

У межах генеалогічних структур найвищими показниками скороспілості (157 \pm 2 діб; $\mathrm{P}>0,999)$, середньодобового приросту $(700 \pm 9$ г; $\mathrm{P}>0,999)$ та довжини тулуба (138 $\pm 2,2$ см; $\mathrm{P}>0,99)$ характеризувалися ремонтні кнурці лінії Нотіс, а скороспі-

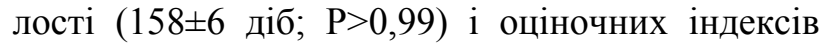

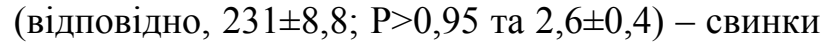
родини Скрастад.

Досліджено кореляційні зв'язки між показниками бальної, індексної та рангової оцінок у межах генеалогічних структур молодняку. Зокрема, встановлено високий коефіцієнт кореляції (r = $-0,825 ; \mathrm{P}>0,999)$ між значеннями індексів Iв та Ip. Значно нижчі коефіцієнти кореляції відмічено у таких парах, як показник незалежних рівнів $\mathrm{i}$ рангової оцінки та індекс Ів і показник рангової оцінки, які становили відповідно: $\mathrm{r}=-0,640$ $(\mathrm{P}>0,99), \mathrm{r}=-0,515(\mathrm{P}>0,95)$.

Висновки. У результаті проведених досліджень встановлено, що за показниками оціночних індексів Ів та Iр у тварин великої білої породи англійської селекції (відповідно, 198 $\pm 2,1$; Р> $0,99$ та $3,7 \pm 0,1 ; \mathrm{P}>0,95)$ кнурці вірогідно переважали своїх ровесниць. У межах породи ландрас найвищими показниками скороспілості (157 \pm 2 діб; Р > 0,999), середньодобового приросту $(700 \pm 9$ г; Р> 0,999), довжини тулуба $(138 \pm 2,2$ см; Р> 0,99) характеризувалися ремонтні кнурці лінії Нотіс. Бальна оцінка тварин за незалежними рівнями $є$ мало інформативною в роботі 3 
тваринами спеціалізованих м'ясних порід імпортного походження. Метод оцінки ремонтного молодняку свиней на основі індексів

\section{БІБЛІОГРАФІЯ}

1. Ващченко П. А. Визначення племінної цінності свиней різними методами // Вісник аграрної науки Причорномор'я - Випуск 1(52). - Т. 2. - Миколаїв, 2010. - С. 76-79.

2. Гетя A. A. Організація селекційного процесу в сучасному свинарстві : Монографія. - Полтава : Полтавський літератор, 2009. - 192 с.

3. Чинаров Ю., Зиновьева Н., Эрнст Л. Метод племенной оценки свиней на основе BLUP //
Iв та Ip є більш точним, порівняно з оцінками за незалежними рівнями й рангами.

Животноводство России. - 2007, февраль. C. $45-46$.

4. Яндиев M. A. Сравнительная эффективность использования разных методов оценки хряков по откормочным и мясным качествам в селекции свиней скороспелой мясной породы : дис. ... кандидата сельскохозяйственных наук : 06.02.01 / Яндиев Мустафа Алиханович. - СанктПетербург - Пушкин, 2008. - 113 с. 